пытается прийти личностное познание. Решение обозначенных противоречий и составляет предмет исследования, очерченного статьей.

Ключевые слова: циифровое пространство, компьютерные технологии, компетентность, методология, противоречия.

TRYFONOVA O. M. Methodological aspects of distribution of supervisors in the development of information and digital competence of future factors of computer technologies.

The article deals with the methodological aspects of resolving contradictions during the development of information and digital competence of future computer technology specialists in the course of teaching physics and technical disciplines in a pedagogical institution of higher education on the basis of the Concept of the development of the digital economy and society of Ukraine for 2018-2020 years. Conditions of creation of the modern educational environment are considered, where the system of contradictions between the infinity of the development of the subject of knowledge of nature and the limited ability of the information and digital competence of the subject of its knowledge must be overcome. The methodological prerequisites for ensuring global changes in the digitalization of education in the direction of its competent modernization are outlined, and the specific tasks of the transformation of education into digital space are determined. The basis of the methodology is the process of thinking development and the formation of a worldview of subjects of learning in a single sensory practical operational environment of self-discipline, competent work with information, models, algorithms.

The aspects of the contradiction between the infinity of the subject of knowledge (unconditional) and the finality (conditionality) of the conditions of knowledge, which are solved in the process of the progressive development of knowledge in the direction of truth, are considered. At points of bifurcation, such contradictions in cognition are solved and "break through" when the preliminary limit of penetration of cognition in the subject of study is achieved. Violations of the previous historical stage of the limits of the student's knowledge of information and digital technologies and the science of their development are stipulated by the fact that, according to their development trends, capabilities and abilities, they are as infinite and unlimited as the subject of the study itself.

Keywords: digital space, computer technology, competence, methodology, contradictions.

DOI: https://doi.org/10.31392/NZ-npu-143.2019.24

УДК 378.147:[811.111:82-83

Хижун Я. В., Дишлева С. М.

\title{
РОЗВИТОК ДІАЛОГІЧНОГО МОВЛЕННЯ У СТУДЕНТІВ ЗВО: АСПЕКТИ ТА ПЕРСПЕКТИВИ ВИКОРИСТАННЯ
}

Сьогочасні реалії свідчать про постійне зростання потреб у комунікації та співпраиі між людьми різних національностей та культур, а змінена система освіти та державний освітній стандарт з іноземної мови спонукають до значних змін у самому підході до прочесу викладання, до перегляду та оновлення дидактичних методів навчання іноземних мов у закладах вищої освіти.

У статті розглядаються дидактичні аспекти діалогічного мовлення в контексті комунікативного підходу до вивчення англійської мови та описано досвід використання деяких методичних стратегій, спрямованих на розвиток діалогічного мовлення студентів, узагальнено науково-методичні засоби розвитку діалогічного мовлення на практичних заняттях $з$ англійської мови у студентів ЗВО та наведено деякі стратегії, спрямовані на покращення та вдосконалення розвитку діалогічного мовлення. Щоб досягнути вільного володіння англійською мовою студентами, викладачу необхідно якомога більшу увагу звертати на розвиток 
комунікативних навичок шляхом як монологічного, так $i$ діалогічного мовлення. Найбільш ефективним методом формування іншомовної комунікативної компетенцї студентів є саме діалогічне мовлення

Статтю присвячено висвітленню та узагальненню науково-методичних засобів розвитку діалогічного мовлення, які використовуються в процесі практичних занять ЗВО. Виділено дидактичні аспекти діалогічного мовлення в контексті комунікативного підходу до вивчення мови, наведено деякі методичні стратегії, спрямовані на розвиток діалогічного мовлення як одного з ключових методів формування іншомовної комунікативної компетенції (напр., “Тематична дискусія”, “Групове дослідження”, “Телефонна розмова” та ін.). Акиентується увага на перевагах використання діалогічного мовлення зі студентами, які вивчають англійську мову як іноземну з метою набуття навичок комунікативної компетениії.

Ключові слова: діалогічне мовлення, англійська мова, комунікативні компетениії, студенти, практика, навички.

Сьогочасні реалії свідчать про постійне зростання потреб у комунікації та співпраці між людьми різних національностей та культур, а змінена система освіти та державний освітній стандарт з іноземної мови спонукають до значних змін у самому підході до процесу викладання, до перегляду та оновлення дидактичних методів навчання іноземних мов у закладах вищої освіти, зокрема, з огляду на це має змінитись і сама система викладання іноземної мови. Комунікативна компетенція набуває все більшого поширення у навчальному процесі, саме у процесі вивчення іноземних мов, та зростає наближення ії до процесу спілкування у реальному житті.

Метою cmammi $\epsilon$ узагальнення науково-методичних засобів розвитку діалогічного мовлення на практичних заняттях з англійської мови у студентів ВНЗ та наведення деяких стратегій, спрямованих на покращення та вдосконалення розвитку діалогічного мовлення.

Завдання статті - виділити дидактичні аспекти діалогічного мовлення в контексті комунікативного підходу до вивчення англійської мови та описати досвід використання деяких методичних стратегій, спрямованих на розвиток діалогічного мовлення студентів. Найбільш ефективним методом формування іншомовної комунікативної компетенції студентів $€$, на нашу думку, саме діалогічне мовлення, адже навчання іноземній мові можливе лише за умови спілкування, процесі, який уможливлює автоматичне перенесення певних навичок і вмінь у реальні умови [1, с. 17].

Неабиякою перевагою діалогічного мовлення $€$, безперечно, “двосторонній характер". Маємо на увазі те, що під час спілкування співрозмовник виступає то в ролі мовця, то слухача, який повинен реагувати на репліку партнера. Тобто процес обміну репліками не може здійснюватися без взаєморозуміння, яке відбувається безпосередньо через аудіювання. Володіння діалогічним мовленням передбачає володіння безпосередніми навичками говоріння та аудіювання, а також наявність у учасників спілкування двосторонньої мовленнєвої активності та ініціативності. Зважаючи на це, у студентів необхідно розвивати вміння ініціативно розпочинати діалог, реагувати на репліки співрозмовника і спонукати до продовження розмови.

Коротко зупинимось на розгляді деяких навчально-методичних стратегій, які спрямовані зокрема й на розвиток саме діалогічної компетенції студентів на практичних заняттях з іноземної мови. Прикладом можуть слугувати такі короткі групові стратегії: 
- Передбачення. Лектор називає тему статті, яка має читатись на занятті, i пропонує в парах обговорити студентам, про що на їхню думку буде йти мова, та зробити припущення стосовно певних ключових моментів. Процедура передбачення застосовується одноразово до процесу читання, з тим, щоб у студентів не було можливості модифікувати свої попередні передбачення. Після прочитання матеріалу доцільно обговорити, наскільки правдивими були ці передбачення[2, с. 28].

- Розмірковуй/Обмінюйся думками. Студентам пропонується певна тема чи проблема для обдумування. Виділяється певний час. Після чого кожен з учасників пари має змогу поділитись із партнером своїми роздумами. Ця стратегія має найбільший ефект у великих групах на початковому етапі вивчення певної теми.

Безперечно, у повсякденному житті ситуації комунікативного діалогічного мовлення виникають спонтанно, вони називаються природніми ситуаціями [3, с. 24]. Такі ситуації, на нашу думку, $є$ базовими у процесі навчання будь-якої іноземної мови. І такі різноманітні життєві ситуації доцільно використовувати на кожному практичному занятті у формі діалогу викладач ®студент.

Склади резюме/Обміняйся думками. Після прочитання певного тексту чи статті студентам пропонується викласти основний зміст двома-трьома реченнями, передавши основну суть прочитанного. Тут мається на увазі поняття, що у лінгвістиці має назву діалогічна єдність (тісно пов'язані та структурно взаємозумовлені висловлювання (особливе структурно-граматичне об'єднання), що $є$ безпосередньою одиницею навчання діалогічного мовлення, коли перша репліка $€$ ініціативною, а друга $€$ реактивною, або ж реактивно-ініціативною [4, с. 19]. Потім у парах обговорюється разом з партнером подібність та розбіжність думок. На кожну частину роботи доцільно виділяти не більше, ніж 3 хвилини часу.

Тематична дискусія. Основна мета цієї короткої групової методики полягає у розвиток навичок усного діалогічного мовлення. Для дискусії підбирається якесь твердження, яке може викликати, як мінімум, дві полярні позиції. Далі академічна група студентів розбивається на пари або підгрупи (по чотири учасники в кожній), залежно від загальної кількості студентів. Кожна з групи обирає думку, яку вони захищатимуть та готуватимуть докази для підтвердження своєї позиції . Далі пари тимчасово розриваються і утворюють нові пари з тими студентами, які дотримуються такої ж позиції. Після чого, повертаються в свої попередні групи і записують основні тези, починаючи їх словами "We are positive of ...". Кожна пара чи група починає представляти свою позицію іншій парі чи групі, після чого вони починають дебатувати, захищаючи свою точку зору. На заключному етапі студенти виробляють спільну позицію в результаті консенсусу, який підтверджується найкращими аргументами.

Безперечно, що застосовуючи цю стратегію, викладач має бути переконаний у тому, що студенти мають навички створювати діалог різних фрунціональних типів, обсяг якого відповідає навчальним програмам чинним для відповідного курсу. Вправи, які застосовуються на кінцевому етапі діалогічного мовлення, належать до рецептивно-продуктивних комунікативних вправ рівня Intermadiate чи навіть Upper Intermediate, таких, що не передбачають створення вербальних опор $[5$, c. 63].

Важливо пам'ятати, що вдосконалення особистісно-профресійної 
комунікативної компетентності студентів відбувається в міжособистісних ситуаціях. Тому показниками професійної майстерності майбутніх педагогічних працівників буде рівень адекватного сприйняття ситуації та вибір раціональних прийомів реагування на неї, що відповідатимуть когнітивному, емоційно-оцінному та поведінковому компоненту діяльності. Це безперечно потребує високого рівня самоаналізу та усвідомлення виконуваних дій. Одна з таких стратегій, коли майбутній спеціаліст матиме змогу додатково отримати наукове пояснення, яке зможе співвіднести з іншими перцептивними і комунікативними характеристиками суб'єкта спілкування, наведена нижче, і називається “Групове дослідження”.

Групове дослідження. Суть методики полягає в тому, що викладачем обирається цікава і мотивована тема для дослідження (наприклад, "Wedding traditions in different countries"). Викладач презентує тему (це може бути аудіювання чи прочитання тексту) та представляє наявні ресурси. Студенти переглядають ресурси, ставлять запитання та поділяють тему на певні півтеми. Далі доцільно поділити академічну групу на окремі підгрупи для дослідження цих підтем [6]. Ці групи проводять дослідження, радячись (діалогічно) стосовно найкращої презентації матеріалу. Роль викладача - постійно слідкувати за перебігом дослідницького процесу, допомагати та слідкувати за часовими показниками. Після чого відбувається безпосередньо сама презентація, до якої залучаються всі члени групи. На завершальному етапі відбувається колективне обговорення матеріалу.

Скомпонуй діалог. Після прочитання невеликого оповідання студентам пропонують уявити, який діалог міг би відбутись між певними персонажами твору. Студенти працюють в парах чи невеликих групках, потім презентують свій діалог аудиторії. Ця методика надає змогу попрацювати спільно та покращити свої навички діалогічного мовлення.

Ще одним різновидом цього виду роботи є такий варіант: на початку заняття студентам пропонується ситуативне фото, на якому зображені головні герої історії, про яку йтиметься далі. Завдання студентів - у формі діалогу передбачити можливий розвиток подій. Аудиторія працює, розбившись на пари (чи невеличкі групи), потім кожна група чи пара презентує свої варіанти. Доцільно вибрати парупереможця, яка скомпонувала найвдаліший діалог.

Телефонна розмова. Вміти вести іноземною мовою телефонні переговори, вільно компонуючи свою думку, - це одна з ознак того, що людина володіє мовою на достатньому рівні. Ця вправа дасть змогу розвинути навички усного діалогу та активізувати базовий лексичний запас з тієї чи іншої теми. Суть завдання полягає в тому, що парі студентів дається певний сценарій, який вони повинні передати у діалозі, чи певне завдання, якого вони повинні досягти, подзвонивши кудись. Чи, інший варіант, обговорити тему, яка була на занятті. Важливим є момент, якого слід дотримуватись у “телефонній розмові", це відсутність візуального контакту між студентами, які проводять діалог. Тобто сидіти вони мають "спина до спини", не бачачи один одного [7].

Отже, щоб досягнути вільного володіння англійською мовою студентів, викладачу необхідно якомога більшу увагу звертати на розвиток комунікативних навичок шляхом як монологічного, так і діалогічного мовлення. Переваги використання діалогічного мовлення полягають в тому, що по-перше, навіть 
сором'язливі студенти будуть задіяні в навчальний процес (адже в парі їм буде легше висловитись, тут доцільно утворювати пари “слабший-сильніший"); подруге, в процес говоріння будуть залучені всі студенти в аудиторії, а не лише декілька; по-третє, це чудовий спосіб попрактикуватись, застосовуючи свої знання з граматичного матеріалу, і цей спосіб практикування може бути постійно урізноманітнений; по-четверте, не потрібно виділяти багато часу на вправи, спрямовані на діалогічне мовлення, доцільно "вкраплювати" їх декілька разів протягом заняття; і врешті, по-п'яте, це чудова практика говоріння, надається час для підготовки своєї думки і можливості її висловлення.

\section{Використана література:}

1. Byram Michael. Teaching and Assessing Intercultural Communicative Competence / Michael Byram. McGraw-Hill, 1997. 56 p.

2. Джанні Стіл, Курт Мередіт, Чарльз Темпл. Методична система "Розвиток критичного мислення у навчанні різних предметів”. Посібники V-VIII. 160 c.

3. Wolfson N. Rules of Speaking / Nessa Wolfson. London and N. Y. : Longman, 1990. 61 p.

4. Черниш В. В. Засоби формування іншомовної комунікативної компетенції у діалогічному мовленні. Іноземні мови. 2011. № 3. С. 15-22.

5. Baker Joanna. Essential Speaking Skills / Joanna Baker, Westrup Heather. Continuum International Publishing Group, 2003. 170 p.

6. https://www.teachingenglish.org.uk/article/having-fun-dialogues

7. https://busyteacher.org/22742-speaking-class-13-go-to-activities-pair-work.html

\section{References:}

[1] Byram Michael. (1997). Teaching and Assessing Intercultural Communicative Competence / Michael Byram. McGraw-Hill. 56 p.

[2] Janni Stil, Kurt Meredit, Charles Templ. Metodychna systema "Rozvytok krytychnogo myslennia u navchanni riznykh predmetiv". Posibnyky V-VIII. 160 p.

[3] Wolfson N. (1990). Rules of Speaking / Nessa Wolfson. London and N. Y. : Longman. 61 p.

[4] Chernych V. V. (2011). Zasoby formuvannia inshomovnoi komunikatyvnoi kompetentsii u dialohichnomu movlenni. Inozemni movy. No. 3. P. 15-22.

[5] Baker Joanna. (2003). Essential Speaking Skills / Joanna Baker, Westrup Heather. Continuum International Publishing Group. 170 p.

[6] https://www.teachingenglish.org.uk/article/having-fun-dialogues

[7] https://busyteacher.org/22742-speaking-class-13-go-to-activities-pair-work.html

ХИжУН Я. В., ДИШЛЕВА С. М. Развитие диалогического разговорного языка у студентов ВУЗ: перспективы и аспекты использования.

Сегодняшние реалии свидетельствуют о постоянном росте потребности 6 коммуникации и сотрудничестве между людьми разных национальностей и культур, $а$ измененная система образования $и$ государственный образовательный стандарт по иностранному языку побуждают к значительным изменениям в самом подходе к процессу преподавания, к пересмотру и обновлению дидактических методов обучения иностранным языкам в заведениях высшего образования.

В статье рассматриваются дидактические аспекты диалогической речи в контексте коммуникативного подхода к изучению английского языка и описывается опыт использования некоторых методических стратегий, направленных на развитие диалогической речи студентов, обобщены научно-методические средства развития диалогической речи на практических занятиях по английскому языку у студентов вузов и приведены некоторые стратегии, направленные на улучшение и совериенствование развития диалогической речи. Чтобы достичь свободного владения английским языком студентами, преподавателю 
необходимо как можно большее внимание обращуать на развитие коммуникативных навыков путем как монологического, так и диалогического вещуания. Наиболее эффективным методом формирования иноязычной коммуникативной компетенции студентов является именно диалогическая речь.

Статья посвящуена освещуению и обобщуению научно-методических средств развития диалогической речи, которые используются в прочессе практических занятий вузов. Выделены дидактические аспекты диалогической речи в контексте коммуникативного подхода к изучению языка, приведены методические стратегии, направленные на развитие диалогической речи, как одного из ключевых методов формирования иноязычной коммуникативной компетенции (напр., “Тематическая дискуссия”, “Групповое исследования”, “Телефонный разговор” и др.). Акцентируется внимание на преимуществах использования диалогической речи со студентами, изучающими английский язык, как иностранный, в русле приобретения навыков коммуникативной компетенции.

Ключевые слова: диалогчческая речь, английский язык, коммуникативные компетенции, студентьл, практика, навыки.

KHYZHUN Y. V., DYSHLEVA S. M. Development of dialogue speech of university students: aspects and perspectives of use.

Current realities indicate a steady growth in the need for communication and cooperation between people of different nationalities and cultures, and the changed system of education and the state educational standard of a foreign language induce significant changes in the approach to the teaching process, to the revision and updating of didactic methods of teaching foreign languages in institutions of higher education.

The article is dedicated to the coverage and generalization of scientific and methodological means of the dialogue speech development, which are used in the process of practical training of universities. The didactic aspects of dialogical speech in the context of the communicative approach to language learning are highlighted, some methodological strategies aimed at developing dialogue speech as one of the key methods of forming a foreign language communication competence (for example, "Thematic discussion", "Group research", "Telephone conversation" etc.). The emphasis is on the benefits of using dialogic speech with students who study English as a foreign language in the context of acquiring skills in communicative competence.

Keywords: dialogic speech, English, communicative competenses, students, practice, skills.

DOI: https://doi.org/10.31392/NZ-npu-143.2019.25

УДК 378. 147

Черняк В. О.

\section{ВИКОРИСТАННЯ НАОЧНОСТІ У ПРОЦЕСІ ВИВЧЕННЯ АНГЛІЙСЬКОї МОВИ У МОЛОДШІЙ ШКОЛІ ЗА ПІДРУЧНИКОМ "FLY HІGH"}

Одним з резервів інтенсифікащії процесу навчання іноземної мови є використання засобів наочності. Наочні засоби при навчанні іноземної мови використовуються для ілюстрації матеріалу, для створення наочної опори при презентації будь-якої ситуаиї̈, стимулюючої спілкування. Особливу важливість представляє ефективність наочності, використовуваної у 